\title{
Moving from reclusion to partial freedom: the experience of family caregivers for disabled elderly persons assisted in a day care center
}

\author{
M ovendo-se da reclusão à liberdade parcial: a experiência \\ do cuidador familiar de idoso dependente assistido num centro-dia
}

\author{
Silvia Cristina M angini Bocchi ${ }^{1}$ \\ Karen Cristina U rtado Cano ${ }^{1}$ \\ Lilian Baltieri ${ }^{1}$ \\ Daniele Cristina Godoy ${ }^{2}$ \\ Wilza Carla Spiri ${ }^{1}$ \\ Carmen Maria Casquel Monti Juliani ${ }^{1}$
}

\footnotetext{
${ }^{1}$ Departamento de Enfermagem, Faculdadede M edicina deBotucatu, Universidade Estadual de São Paulo. 18618-970 Distrito de Rubião Júnior Botucatu SP. sbocchi@fmb.unesp.br ${ }^{2}$ Coordenadora do Centro deConvivência do Idoso Aconchego, Botucatu - SP.
}

Abstract This study aimed at understanding the interactional experience between family caregivers and disabled elderly persons supported in a Day Care Center according to the caregiver's perspective. It also aimed at developing a representative theoretical model for the events experienced by such caregiver. The Grounded Theory was used as methodological framework whereas I nteractional Symbolism served as the theoretical framework. Observation and interviews were used for data collection. The following phenomenon arose from theresults: feeling of support by the Day Care Center, by the strength of the bond with the elderly and by spirituality in order to continue playing the challenging role of a family caregiver for a disabled elderly person. The study made possible to understand that, among these three supporting cornerstones for coping with the burden generated by the family caregiver role, the care model promoted by the Day Care Center was the intervenient variable in the process of improving the quality of life of the family caregiver-disabled elderly person binomial. This allowed the identification of the main category - moving from reclusion to partial freedom: the experience of family caregivers for disabled el derly persons assisted in a Day Care Center. Key words Elderly, Family, Day care
Resumo 0 estudo tevecomo objetivos: compreender a experiência interacional cuidador familiaridoso dependente apoiada por um Centro-Dia (CD), segundo a perspectiva do cuidador familiar, e desenvolver um modelo teórico representativo da experiência vivida por ele. Utilizou-se como referencial metodológico a Grounded Theory e como referencial teórico o Interacionismo Simbólico. As estratégias para a obtenção dos dados foram a observação e a entrevista. Dos resultados emergiu o fenômeno: sentindo-seapoiado pelo CD, pela força do vínculo com o idoso epela espiritualidadepara continuar desempenhando o papel desafiante de cuidador familiar deidoso dependente. 0 trabalho permitiu-nos compreender que dentre esses três pilares de apoio para enfrentamento da sobrecarga gerada pelo papel de familiar cuidador dependente, o modelo assistencial promovida pelo $C D$ é o que se configurou como variável intervenienteno processo demelhora da qual idadedevida do binômio cuidador familiar-idoso dependente. Isto nos possibilitou identificar a categoria central - movendo-se da reclusão à liberdade parcial: a experiência do cuidador familiar de idoso dependente assistido num $C D$.

Palavras-chave Idoso, Família, Assistência diurna 
Beginning the study

Since the 1940s, Brazil has experienced an inversion process in its mortality curves, and a decline in the number of deaths caused by infectious diseases has been observed with a concomitant increase in the number of deceases resulting from non-transmittable chronic disorders and external causes. This process is known as theepidemiological transition phenomenon. It has occurred in all currently developed countries, whose elderly populations are increasingly more expressive ${ }^{1}$.

This epidemiological transition phenomenon has defined a new population profile worldwide and caused a great impact on the various segments of society, which can be explained by the fact that, on one hand, a decrease in fertility and in mortality due to childhood diseases has been observed, while, on the other, an increasing number of chronic-degenerative diseases and typical disorders of older age has also arisen as a counterpart of present day life characteristics ${ }^{2}$.

The frequency of chronic diseases and the present longevity of Brazilians are the two major causes for increased rates of disabled elderly persons. Prevention of chronic and degenerative diseases, health care for disabled elderly persons and support for family caregivers represent new challenges to the health care system installed in Brazil ${ }^{3}$.

This situation implies a rearrangement of Brazilian public policies with the purpose to favor the implementation of holistic measures capable of providing improvement to the quality of life of this population group. However, what is observed in our country is that elderly persons are the ones mostly affected by the crisis influencing the country's welfare policies, particularly those concerning health care 4 .

In face of this reality, the family constitutes the major support system to the elderly despite the difficulties experienced at contemporary times.

The literature shows that giving care to the disabled el derly brings a variety of adverse effects and acknowledges the emotional impact experienced by family members caring for persons with mental disorders or other problems resulting from ageing. Such emotional impact or burden has been defined as: physical, psychological or mental, social and financial problems experienced by family members as a result of giving care to diseased elderly persons ${ }^{5}$.

The family presents material and emotional needs, including the need for information. The material aspect includes financial resources, hous- ing issues, transportation and access to health care services. On the other hand, the caregiving family needsinformation on how to providecare, including the adaptation of the environment to the elderly person. Additionally, emotional support aswell as a carenetwork connecting the family to support services and ways to ensure quality of life to major caregivers are also important ${ }^{6}$.

It is in this context that thenon-institutionalized elderly care modality arises in Brazil under the denominations of Cohabitation Center, Day Care Center (D.C.C.), Day Care Hospital, Home House and Sheltered Workshop, which aim at assisting older persons during a certain period of the day?.

Theneed to carry out thisstudy emerged from out participation in a community service project at the Elderly Day Care Center (Centro de Convivência do Idoso - CCI - Aconchego), located in a city of São Paulo state, Brazil, as well as from the lack of studies assessing the impact of this type of institution as regards the binomial family caregiver-disabled elderly. Thesewerethereasons which motivated us to conduct this study: to understand the interactional experience between the family caregiver and the disabled elderly supported by a D.C.C. for the elderly according to the caregiver's perspective; and to develop and validate a representative theoretical model of his experience.

\section{Approaching the method}

This is a qualitative investigation, conducted in accordance with ethical precepts, on family caregivers for disabled elderly persons assisted at $\mathrm{CCl}$ - Aconchego in the city of Botucatu, São Paulo, Brazil. The institution relies on physical facilities provided by the Municipal Administration with afternoon working hours and 35 places for elderly disabled individuals at somelevel. N onetheless, it is not capable of assisting all those seeking for its services, thus keeping a certain number of unattended candidates. Its staff consists of a technical team composed of hired professionals: a physical therapist, an occupational therapist and three recreation aides; of volunteers: an undergraduate nursing student, a speech therapist, a social worker, two psychologists; as well as by grant-supported students: one from the field of nursing and onefrom the field of nutrition. In addition to the volunteers composing thetechnical team, it is also supported by community members who are responsible for preparing afternoon snacks and 
for helping theelderly persons during recreational activities, among others.

In order to conduct this investigation, family members who identified themselves as those assuming the major unpaid responsibility for the elderly home care were regards as actors.

Interviews were carried out in their own homes by respecting their availability so that they could confidentially answer the following guiding question to the researchers: what has your experience as a family caregiver for a disabled elderly person assisted by D.C.C. been like?

When the recording of each interview was completed, it was transcribed and analyzed according to the basic strategies presented for category formation by the Grounded Theory methodological framework ${ }^{8}$.

Categories, according to the authors, are abstractions of the phenomenon observed in the data, and they form the main analysis unit of the Grounded Theory. Thetheory is developed through thework conducted with the categories, which leads to the emergence of the core category as a result of the analysis, which is usually a process ${ }^{8}$.

Theoretical saturation was obtained after the analysis of the 10th interview. Thefamily caregivers were usually females due to the difficulty in finding males playing such role. The level of relationship was distributed between nine daughters and one wife who were 38 to 61 years old and had been experiencing that condition for 01 to 15 years.

A point was made in meeting with the actors participating in this study as well as with other family caregivers for the disabled elderly assisted by D.C.C. in order to present the results of this study during the monthly meeting held by the institution so that they could have an opportunity to evaluateand validatethetheoretical model as representative for their experiences.

Theresults were discussed in thelight of Symbolic Interactionism according to Charon?

The experience of the family caregiver for the disabled elderly assisted by the D.C.C.

The phenomenon identified

Data analysis in the light of the Grounded Theory allowed for understanding theexperience of the family caregiver for the elderly assisted by the D.C.C. when the following phenomenon emerged: feeling supported by the D.C.C., by the family tieand by spirituality in order to continue playing the challenging role of a family caregiver for a disabled elderly person.

The phenomenon will be described in the form of concepts stemming from the actors' ex- periences, according to the components in the process: themes, categories, subcategories and elements.

Feeling supported by the D.C.C., by the family tie and by spirituality

in order to continue playing

the challenging role of a family caregiver

for a disabled elderly person

The phenomenon shows that the family caregiver for the disabled elderly elects three supporting cornerstones (instrumental, mental and spiritual), which are: theD.C.C., thestrength from the tie with the elderly person and spirituality as necessary to lead them to the physical and mental balance that is essential to cope with the burden and to continue playing their social role. The D.C.C. is distinguished as a care model that could be implemented and subsidized by the State as a strategy of support for the binomial family caregiver-disabled elderly within the country's Public Health Policies. The phenomenon joins two themes: feeling forsaken and finding support in the D.C.C., in family ties and in spirituality.

Theme A. Feeling forsaken

The family member experiencing the burden posed by the challenging role of being thecaregiver for a disabled el derly feels forsaken as financial and psychological support from the family and the social network or from the State is not provided. N or does he have the necessary knowledge to play such role, which also occurs to those with enough financial resources, considering the difficulty in finding a competent secondary caregiver to meet the patient's needs. Due to the effects of the experience, he perceives the mental suffering which extends to other family members during the process. This theme gathers five categories: feeling unprepared to deal with the disabled elderly, not finding support, interrupting his life plan due to the burden, perceiving his and his family's sickening as an unpleasant experience.

A1. Feeling unprepared to deal with the disabled elderly

At first, the family experiences a conflictive situation when facing the disease signs and symptoms, especially the elderly behavioral changes and the family members' impotence to manage the problems due to the lack of knowledge concerning physiopathology and appropriateinterventions.

I was not prepared to take care of a sick person. I had never taken any courses on caregiving, so | felt completely lost. 
I had heard about that disease on television (Alzheimer's disease), and I thought it was horrible, and now it has happened in my house.

\section{A2. Not finding support}

It refers to family caregivers who require support from the State due to financial difficulties and who cannot count on support from the family or from the social network in order to continue playing his role. It also refers to those who do not have financial problems to hire a secondary caregiver, but who face difficulty in finding one according to the competencies that they believe to be essential for such position.

The financial difficulties really disturb us. Every resource necessary to care for the elderly has to be purchased. The family has to provide everything.

I don't get any support from my family.

...nowadays, it's very complicated to hire someone to look after an elderly relative so that the family caregiver can take a little more care of his own life.

I feel forsaken by the State.

\section{A3. Interrupting his life}

plan due to burden

In face of thelack of support and the great demand for his availability to provide the care required by the disabled person, the family caregiver renounces his daily activities and entertainment, thus feeling burdened and many times setting his own life on stand by.

You end up annihilating yourself; you don't do things becauseyou feel afraid that something might happen to your elderly relative.

I feel that I am on stand by, I have given up all the things that I used to do for myself.

I don't have much time to rest.

\section{A4. Perceiving his}

and his family's sickening

It refers to the experiencein which the caregiver's burden when playing his rolewithout support is not restricted to himself, but the mental suffering extends to other family members as if it werea phenomenon characterized by family sickening.

I became depressed; I think the whole family did. I believe the depression started because of my mother's condition.

If the elderly person does not feel well, thefamily caregiver doesn't feel well either.
A5. As an unpleasant experience

When experiencing the family caregiver role, his life is transformed, and he cannot find satisfaction in everyday living. It is marked by suffering and sorrow, which denounces psychological reactions to those who survive significant losses even though they have overcomethe worst phase of caring for a disabled elderly person.

I think it's worse for the caregiver than it is for the patient himself.

In fact, a caregiver's experience is an exhausting task.

Theme B. Finding support in the D.C.C., in family ties and in spirituality

Thefamily member elects three cornerstones necessary for continuing playing his challenging role of a disabled elderly caregiver, which are: the D.C.C., the tie with the patient and spirituality. These are elements supporting the instrumental, mental and spiritual conditionsthat can lead him back to the physical and mental balance which is essential for coping with the burden generated by his role. This topic consists of three categories: feeling supported by thetie with the patient; becoming stronger in spirituality; feeling supported by the D.C.C.

\section{B1. Feeling supported by the family} tie with the patient

To continue playing his role, the family member seeks for strength in a set of feelings that bind him to theelderly person and which is based on affection and solidarity for a person who is experiencing a moment of fragility in face of a disease without perspectives of improvement in senescence.

It's a disease that has no cure, at least for now. So, I must endure it.

I do it for love and become rather attached to God. I really love my husband.

B2. Strengthening oneself in spirituality Thedisabled elderly family caregiver turns toward God moved by the belief and trust in a transcendental, omnipotent and omniscient being who is capable of emanating the strength necessary for his physical and mental balance while he endures the grief and misfortune from playing his role.

I believe that I can rest when I support myself on God. It's for this reason that I try to have a moment with God. 
B3. Feeling supported by the D.C.C. When experiencingtheservicegiven by the D.C.C., the family caregiver positively evaluates the care model developed by the professionals and volunteers in favor of the family caregiverdisabled elderly binomial. The process shows that he gradually develops enough confidence on the institution so as to easily place his dear one under its care and to take advantage of informational and mental support for coping with the situations resulting from the disease, in addition to perceiving the re-socialization of the elderly patient. Thus he undertakes a movement and begins to enjoy his free time, although partially, in order to resume his life plan and consequently recover self-esteem. This category consists of four sub-categories: overcoming the caregiver's and the elderly person's resistance; learning to deal with the elderly person's disability; feeling satisfied with the service; partly resuming his life plan.

\section{Overcoming the caregiver's}

and the elderly person's resistance The elderly person's family caregiver, when finding the D.C.C. as a possibility of support for the burden experienced, ends up showing two types of resistance: the feeling of guilt for leaving his relative in the Institution for a few hours and the elderly person's refusal to re-socialize. This sub-category gathers two elements: feeling guilty at first and coping with the elderly person's resistance to attending the D.C.C.

At first, I had theimpression that my husband was going to an asylum. Astime passed, however, I realized that the treatment was different.

At first, you feel a little remorseful for leaving your older relative at $\mathrm{CCl}$. I felt like I was abandoning him.

At first my older relative didn't want to go, but he got used to the idea later.

\section{Learning to deal}

with the elderly person's disability

With the knowledgeobtained from the professionals at the D.C.C. and through the experience itself, the family caregiver gradually learns to operationalize strategies to cope with the everyday problems generated by the elderly person's disease without consuming too much of his own energy. Heacknowledges that in order to continue playing his roleand takegood care of the patient, it is necessary to preservehimself psychologically.
When you don't know about the disease, you become irritated; she keeps moaning at times, and then you say: M other, stop! That gets into my head, and then I play some music. I've learned that you eventually learn as you go through the experience. She likes music. She pays attention to the music and stops moaning; then I leave and go to another room.

I didn't know exactly what the disease was; I only knew that it progressed; I didn't know how to deal with the situation, and it was through D.C.C. that we learned to accept the disease and to live with my mother the way she is.

Feeling satisfied with the service

At D.C.C., the caregiver finds an environment that provides peace, allowing him to express his emotions, clarifying doubts concerning his relative's disease, and, at the same time, he perceives the elderly improvement. As a result, the family caregiver becomes confident on the service, leaves his dear one at the Institution and takes advantage of this free time to resume his life plan. This sub-category embodies three elements: the D.C.C. hel ping the elderly person, the D.C.C. helping thefamily caregiver and theD.C.C. helping the family caregiver-disabled elderly binomial.

I sincerely valueit, in all aspects, for the good it has done to my mother, because she has improved $300 \%$, not only $100 \%$.

When she began to attend, she didn't speak. All she wanted to was sleep because she couldn't sleep all night, so he slept during the day. ... then, when she began to go there, she started to improve. A month and a half later, she started to talk, to participate in things a little. Today, she is talking and greeting people.

I think that my mother's self-esteem has improved a lot after being with people her age and with the D.C.C. professionals.

I'velearned a lot from D.C.C. I'velearned that I must continue leading my life without feeling guilty. In the past, I didn't feel good when I went out.

D.C.C. has helped me not to feel like an empty ball or a withered leaf and to start dedicating a few hours to myself.

D.C.C. is for both the elderly person and the family. The elderly person's relationship with people his age takes him away from isolation while the caregiver acquires knowledge to deal with situations experienced with older people and even changes his values. 
Partly resuming his life plan

The support provided by the D.C.C. allows the caregiver to partly resume his life plan which was interrupted when his role was taken up. He acquires self-confidence to deal with the older person's disability, which, associated with free time, gives him the opportunity of self-care and self-esteem recovery.

Today, I try to enjoy each moment in my life, because the beginning of my experience as a family caregiver was very difficult. O ver time, I learned to deal with my older relative, that is, I learned to cope with the difficulties.

At the beginning, I used to be a little depressed, then I got used to taking care of the older person more easily.

Discovering the core category

The strategy used to discover the core category was to inter-relate the two themes aiming at comparing and analyzing them in order to understand how the interaction between their components occurred. This strategy allowed for identifying that the categories, subcategories and el ements composing the phenomenon undertake a movement in search for support in face of the burden generated by the experience, leading to the identification of the core category as: moving from reclusion to partial freedom: the experience of family caregivers for disabled elderly persons assisted by a D.C.C.

The process of discovery of the core category began to corroborate our first perceptions when wetook possession of all the diagrams that showed us the two themes and all their components.

At that moment, it was possible to visualize, in the chain of categories composing the first theme feeling forsaken, a movement of meanings which conducted us to the second theme finding support in theD.C.C., family ties and spirituality; nevertheless, the day care center constituting an essential variable for the caregiver to undertake the movement towards the partial resumption of his life plan.

Based on the interrelation of the two topics composing the phenomenon, it was possible to abstract the theoretical model denominated: moving from reclusion to partial freedom: the experience of family caregivers for disabled elderly persons assisted by a D.C.C.

Feeling forsaken is the first challenging process experienced by thefamily caregiver upon the realization that he is unprepared to deal with the disabled older person sinceheisnot instrumentalized with knowledge concerning disease physiopathology or the necessary interventions to cope with problems. Added to such condition is the lack of support from the family or factors preventing the help of a secondary caregiver as well as the inexistence of a specific service in the Brazilian Unified Health System to promote care to the family caregiver-disables elderly binomial. In such circumstances, he eventually interrupts his life plan in face of the burden generated by his role and perceives his own sickening as well as that of his family.

It is an unpleasant experience that leads him to undertake movements in search for energy to continue providing his relative with care. The cornerstones that help him achieve physical and mental balance and seek help are: the strength of the tie established with the elderly person and spirituality.

In this search process, he eventually finds, in the D.C.C., the third cornerstone that will support him with the partial resumption of his life plan. He feels satisfied with the service since it provides him with a peaceful environment which allows him to express his emotions, clarifying his doubts and leading him to learn how to deal with the disability caused by his relative's disease, and, at the same time, perceives the elderly person's improvement. As a result, he becomes confident on the service, leaves his dear person in the Institution and uses his time for self care.

By going through the experience, the caregiver eventually feels supported by the service provided by the D.C.C. and evaluates it as caremodel for the family caretaker-disabled elderly binomial which promotes informational and mental support in addition to the re-socialization of the elderly person and his caregiver.

H ence, we presented thetheoretical model to the actors participating in this study, who evaluated and validated it as representative for their experiencessinceit was capable of portraying their experiences with the support provided by D.C.C.

\section{Discussing the results}

The study made it possible to understand the experience of family caregivers for disabled elderly patients assisted by a D.C.C. as well as to develop and validate a representative theoretical model for it.

The decision to conduct this study, based on atheoretical and methodological perspectivesupported by the Grounded Theory and Symbolic Interactionism, allowed for advancing our knowledgeconcerning thestudied object by understanding that, among the three supporting corner- 
stones for coping with the burden generated by the role of family caregivers for disabled elderly persons, the care model promoted by the D.C.C. was configured as an intervenient variable to change the course of such experience, which is surrounded by feelings of abandonment and circumscribed to the elderly homecare, for the partial resumption of the caregiver' life plan.

This process only takes place during experiences in which the family caregiver can feel supported in the process of caring; when he becomes secure about leaving the patient to resume outside activities, which will awaken the feeling of freedom from an exhausting role ${ }^{10}$.

Partial isolation is one of the aspects that generate burden, particularly due to changes in lifestylewhich reduce, modify and cause dissatisfaction in the family caregiver's social life as a result of the limiting conditions posed by the disease, bringing feelings of isolation to relationships circumscribed to household activities ${ }^{10}$.

The functional and cognitive deficit, personality or behavioral change ${ }^{11,12}$ as well as communication change ${ }^{13}$ are alterations that eventually compromise the patient and the family ${ }^{14}$.

The burden is frequently associated with the level of physical disability ${ }^{15,16}$, and the compromising of ambulation is a significant factor interfering with the caregiver's quality of life; however behavioral change is what causes the most exhaustion ${ }^{17}$.

By evaluating family caregivers for CVA patients, it was observed that $55 \%$ of them showed evidence of psychological burden, particularly those who were nursing patients with dementia and behavioral disorders ${ }^{18}$.

Aspects related to mental health in chronic disease are more stressful to caregivers than physical aspects. Among the problems found are behavioral disorders (apathy, agitation, perambulation) and mood disorders (depression, anxiety) ${ }^{19}$.

Additionally to the aspects above, there are financial difficulties to hire a secondary caregiver and to cover the extra expenses resulting from giving home care to a disabled person ${ }^{20}$ as well as a lack of knowledge concerning the most appropriateways to assist the patient, which eventually generates dissatisfaction, incapacity and insecurity in taking up the caregiving role ${ }^{21}$.

Exposed to physical and mental burdens, family caregivers are affected by tiredness, sleep disorders ${ }^{13,22}$, cephalalgia, weight loss or gain ${ }^{23}$ and high blood pressure ${ }^{13}$, which contributes to high depression levels among such individuals sand is regarded as unfavorable to the caregiving process ${ }^{17}$.
However, this study shows that the access of the family caregiver-elderly disabled binomial to the service provided by the D.C.C. foresees the possibility of partial resumption of the life plan which had been abandoned by the caregiver in solidarity for a relative that is experiencing hard times in his senectitude.

The experiencewith support revealed that the caregiver became confident and unworried about leaving the elderly person under the care of the Institution's professionals and volunteers when he realized that it provided informational and psychological support for coping with the situations resulting from the disease, in addition to promoting re-socialization for both. Becoming self-confident about dealing with theelderly person's disability and now counting on his partial free time while the patient is being nursed by the D.C.C., the caregiver redirects his attention to selfcare, which allows for the recovery of his selfesteem and the possi bility of having better quality of life to continue playing his social role.

According to Symbolic Interactionism, actions are caused by an active decision-making process by the action subject. This process involves the definition of a situation, which, in its turn, involves interaction with oneself and with others. $H$ ence, the definition of a certain situation made by an actor is the key factor to how action will occur. The human being is free in what he does. All of us define the world on which weact and part of such definition is ours; it involves a conscious choice, the direction of our actions in face of this definition, the identification of such actions and of the actions by others, and our own redirection?.

In view of the movement undertaken by the experience, we suggested that the caremodel operationalized by the D.C.C. as a possibility of support to the family caregiver-disabled elderly binomial to be implemented by Brazilian Public $\mathrm{H}$ ealth Programs.

These are the reasons showing that the service types most appreciated by caregivers were those of home care and help with housework. However, those provided by the day hospital and the care in the form of free time enabled them to rest and were, therefore, the most valued ${ }^{22}$.

It is noticed that these types of support are important for the performance of the caregiver's role as shown by studies comparing individuals participating in this type of care with non-participants. The results show caregivers with lower depression levels and greater ability to play their roles $^{15,24}$ and, hence, with better quality of life.

In spite of the changes occurring in the Brazilian scenario in relation to social protection 
policies for the elderly, such policies are still very restricted as regards the provision of public health services and programs, which is exemplified by the amplitude of their intervention. The State presents itself as a punctual partner with reduced responsibility that attributes to the family the major role in home care for the disabled elderly. It is found that more powerful policies lack as regards the roles attributed to families and to support under the responsibility of a service network provided to disabled elderly individuals and their families. It is pointed out that new forms of care and new approaches to disabled ageing and the caregiver must exist in public health policies ${ }^{3}$.

Hence, this study contributes by proposing a care model for the family caregiver-disabled elderly binomial which has been recommended and validated by the social actors experiencing the possibility of counting on the support provided by a D.C.C.

\section{Making final considerations}

Thisstudy, under thetheoretical and methodological perspective supported by the Grounded Theory and Symbolic Interactionism, allowed for understanding the experience of family caregivers for disabled elderly persons assisted by a D.C.C. and led to the development and validation, by the subjects themselves, of a theoretical model that is representative of their experiences and has been denominated: moving from reclusion to partial freedom: the experience of family caregivers for disabled elderly persons assisted by a D.C.C.

The conduction of this study made it possibleto understand that, among thethree supporting cornerstones (spirituality, strength of the tie with the elderly person and the D.C.C.) for coping with the burden generated by the role of a family caregiver for a disabled person, the care model promoted by the D.C.C. was configured as an intervenient element for changing the course of the caregiver's experience, which is surrounded by feelings of abandonment.

The experiencewith support reveal ed that the caregiver became confident and unworried about leaving the elderly person under the care of the Institution's professionals and volunteers when he realized that it provided informational and mental support for coping with the situations resulting from the disease, in addition to promoting re-socialization for both. Becoming selfconfident about dealing with the elderly person's disability and now counting on his partial free time while the patient is being nursed by the D.C.C., the caregiver redirects his attention to selfcare, which allows for the recovery of his selfesteem and the possibility of having better quality of life to continue playing his social role.

Based on this knowledge, we suggest that the State implement the care model discussed in this study as one of the strategies for support to the family caregiver-disabled elderly binomial.

\section{Collaborations}

SCM Bocchi conceived the research project, analyzed and argued the data, as well as elaborated the report of the research. KCU Cano and L Baltieri collected and assisted in the collect and data analysis. DC Godoy, WC Spiri and CM CM Juliani assisted in the data discussion and elaboration of the paper.

\section{Acknowledgement}

We are thankful the Fundação de Amparo à Pesquisa do Estado de São Paulo (Fapesp) for the financial support of this research. 


\section{References}

1. M inistério da Saúde [site na Internet]. Brasília: Ministério da Saúde [acesso 2004 maio 6]. Programas e projetos: doenças cardiovasculares [3 telas]. Disponível em: http://www.saude.gov.br

2. Marcon SS, Waidman MAP, Carreira L, Decesáreo MN . Compartilhando a situação de doença: cotidiano de famílias de pacientes crônicos. In: Elsen I, M arcon SS, Santos M R, organizadores. 0 viver em família e sua interface com a saúde e a doença. M aringá: Eduen; 2002. p. 311-335.

3. Karsch UM . Idosos dependentes: famílias e cuidadores. Cad Saude Publica 2003; 19(3):861-866.

4. Fernandes M GM, Almeida CB. Processo de pensamento alterado em idosos na vivência asilar. Nursing (São Paulo) 2001; 4(34):22-25.

5. Cerqueira ATAR, Oliveira NIL. Programa de apoio a cuidadores: uma ação terapêutica e preventiva na atenção à saúde do idoso. Psicol USP 2002; 13(1):133-150.

6. Caldas CP. Envelhecimento com dependência: responsabilidade e demandas das famílias. Cad Saude Publica 2003; 19(3):733-781.

7. Yamamoto A, Diogo MJD. Os idosos e as instituições asilares no município de Campinas. Rev Latino-Am Enfermagem 2002; 10(5):660-666.

8. Glaser BG, Strauss AL. The discovery of grounded theory. New York: Aldine; 1967.

9. Charon JM. Symbolic interactionism: an introduction, an interpretation, an integration. New York: Prentice Hall; 1989.

10. Bocchi SCM. M ovendo-se entre a liberdade e a reclusão: vivendo uma experiência de poucos prazeres ao vira-ser um cuidador familiar de uma pessoa com AVC [tese]. São Paulo: Escola de Enfermagem/USP; 2001

11. Coughlan AK, Humphrey M. Presenile stroke: longterm outcome for patients and their families. Rheumatol Rehabil 1982; 21(2):115-122.

12. Silliman RA, Fletcher RH, Earp JL, Wagner EH. Families of elderly stroke: effects of elderly stroke patients: effects of home care. J Am Geriatr Soc 1986; 34(9):643-648.

13. Williams SE, Freer CA. Aphasia: its effect on marital relationships. Arch Phys Med Reabil 1986; 67(4):250-252.

14. Bronstein KS. Psychosocial components in stroke: implications for adaptation. Nurs Clin North Am 1991; 26(4):1007-1017.
15. Printz-Feddersen V. Group process effect on caregiver burden. J N eurosc Nurs 1990; 22(3):164-168.

16. Cassidy TP, Gray C. Stroke and the carer. Br J Gen Pract 1991; 41(3):267-268.

17. Carnwath TCM, Johnson DAW. Psychiatric morbidity among spouses of patients with stroke. $\mathrm{Br}$ Med J 1987; 294(6569):409-411.

18. Béthoux F, Calmels $P$, Gautheron V, M inaire $P$. Quality of life of the spouses of stroke patients: a preliminary study. Int J Rehabil Res 1996; 19(4): 291-299.

19. Draper BM, Poulos CJ, Cole AMD, Poulos RG, Ehrlich FE. A comparison of caregivers for elderly stroke and dementia victims. J Am Geriatr Soc 1992; 40(9):896-901.

20. Bocchi SCM. Vivenciando a sobrecarga ao vir-aser um cuidador familiar de pessoa com acidente vascular cerebral (AVC): análise do conhecimento. Rev Latino-Am Enfermagem 2004; 12(1):115-121.

21. Khumalo FY, Zungu BM. An investigation into competence of families of patients who are nursed at home after a stroke with emphasis on their education by the nursing staff. Curationis 1995; 18(2):6-8.

22. McLean J, Roper-Hall A, Mayer P, Main A. Service needs of stroke survivors and their informal carers: a pilot study. J Adv Nurs 1991; 16(5):559-564.

23. Robinson-Smith G, M aboney $C$. Coping and marital equilibrium after stroke. J Neurosc Nurs 1995; 27(2):83-89.

24. Ross S, Morris RG. Psychological adjustment of the spouses of aphasic stroke patients. Int J Rehabil Res 1988; 11(4):383-386.

Artigo apresentado em 09/03/2007

Aprovado em 14/06/2007

Versão final apresentada em 20/08/2007 